\title{
The Error In Drawing Graphic Of Quadratic Function In PBL Model By Using True Or False Strategy With GeoGebra-Assisted
}

\author{
Lukmanul Akhsani ${ }^{1}$, Erlin Nurhayati ${ }^{2}$ \\ ${ }^{1}$ Universitas Muhammadiyah Purwokerto, ${ }^{2}$ SMP Negeri 5 Purwokerto \\ *luk_akh@yahoo.com
}

\begin{abstract}
Quadratic function is one of the important topic in mathematics. The purpose of this study is to describe the mistakes made by students when drawing a quadratic function graph. In this research, the focus of the problem is what type of mistakes made by students in drawing a graph of quadratic functions. The form of error here referred to an error in doing the exercise of drawing quadratic function graph in learning with the PBL model using a true or false strategy assisted by GeoGebra application. The conclusion of this research states that the error in drawing quadratic function graph is dominated by procedural errors. PBL model with true or false strategy with the help of GeoGebra application can be an alternative learning to overcome students' mistakes in drawing quadratic function graphs.
\end{abstract}

Keywords: the error, Problem, true or false, mathematic.

Received: 2020-08-06

/ Accepted: 2020-10-31

/ Publised: 2020-11-01

\section{Introduction}

Mathematics is a very important subject in school. We can solve everyday problems easily, because we are trained to think systematically through regular steps. When we learn mathematics, we are also trained to be thorough and careful, one of the example is in doing on math exercise through calculations and logic. Our creativity and imagination are also trained, for example in drawing graphics. One of the special graphs is the graph of quadratic function. Lots of application of quadratic functions. The shape of the curve that is very attractive also becomes a beautiful thing when applied in bridge construction. Another application is also in determining the speed of objects and analyzing falling objects. This makes the topic of quadratic function very important and interesting to study. Students need to master the ability in drawing quadratic graph functions. However, there are still many obstacles in understanding it.

Based on the results of the observation in class 9H, SMPN 5 Purwokerto, it shows that students do not have problems in operating numbers. However, when studying the material that involves algebraic forms, students begin to have difficulty in operating it. In the material of drawing quadratic functions there are also parts where students look for the intersection of curves with the $\mathrm{x}$-axis and $\mathrm{y}$-axis by factoring or other methods related to the operating algebraic forms. This becomes an obstacle for students in drawing a graph of quadratic functions.

Based on the explanation above, it is necessary to have an innovations to solve the problem, one of them is through learning with Problem Based Learning (PBL) with the true or false strategy assisted by the GeoGebra application. The increase in learning motivation in the experimental class using the problem-based learning (PBL) approach was significantly better than the control class using the conventional approach. (Arief \& Sudin, 2016). Through this learning, it helps the students to think step by step in drawing a graphic of quadratic function. Scientific reasoning skills should be trained in all students who are at the concrete operational thinking and formal operational stages (Shofiyah \& Wulandari, 2018). Learning by using true or false strategies and conventional learning can improve learning outcomes. (Erikalisdiana \& 
Jayadinata, 2016). Students can also understand the shift of quadratic function graph easily through group discussion activities, wherein the group is given a problem that they must find a solution and conclude the point of the problem. PBL model significantly increased the problem solving ability by $17.73 \%$ and student cognitive learning outcomes by $23.65 \%$. (Supiandi \& Julung, 2016). Through the application of the problem based learning model can improve students' critical thinking skills in learning. (Nafiah \& Suyanto, 2014)

The purpose of this study is to describe the mistakes made by students when drawing a quadratic function graph. In this study, the focus of the problem is what type of mistakes made by students in drawing a graph of quadratic functions. The Material of quadratic functions are taught by using the PBL model with a true or false strategy assisted by the GeoGebra application. So, the form of error here referred to an error in doing the exercise of drawing quadratic function graph in learning with the model.

According to Arends in Trianto (2014), PBL has the following characteristics:

a. Submitting a question or problem.

The initial step of PBL is to present the next problem based on the problem that found in concepts, principles and rules. That problems are authentically addressed with reference to real life, avoiding simple answers and allowing a variety of solutions.

b. Focusing on the link of interdisciplinary science

The problem that will be investigated has been chosen really real so that the solution is done coherently. Students also review the problem from many subjects.

c. Authentic inquiry.

Students do the authentic investigations to find real solutions for real problems. Students must analyze and define problems, develop hypotheses and make predictions, gather and analyze information, conduct experiments (if needed), make inferences and formulate conclusions.

d. Producing products and marketing them

PBL requires students to produce certain products in the form of real creation or artifacts and demonstrations that explain or represent the form of problem solving that they found. In this case, it can be in the settlement of the problem in the results of the discussion.

e. Collaboration

PBL conducted by students who cooperate with each other, most often in pairs or in small groups. Working together provides motivation to sustainably engage in complex tasks and expand opportunities to share inquiry and dialogue and to develop social skills and thinking skills.

According to Silberman (2007), the steps for a True or False Learning Strategy are as follows:

a. The teacher makes a list of statements that are suitable with the material of the subject, that contain of which are true and false. Statements are written on each card separately and make sure the number of statements is in accordance with the number of students.

b. Distribute card to student.

c. When the subject is finished, ask each student to read the card that he got and get a class opinion about the statement being true or false.

d. The teacher gives a response about the truth or the fault for each of these cards

e. The teacher gives conclusions.

The PBL Model activities with the True or False Strategy assisted by the GeoGebra Application are as follows:

a. Students are given motivation and apperception by the teacher. 
b. Students are given a card that contains a statement / question with answers that have true or false values where later, at the end of learning, students write whether the statements / answers on the card are true or false.

c. The teacher gives some problem cases in math to students that will be solved together through group discussions.

d. Students present the results of their discussion in front of the class.

e. Students do an evaluation.

f. Students regularly look back on what they have done before.

g. Students with the teacher conclude the material that they have learned.

h. Students check the cards that have been saved in their pockets.

Subaidah in Layn (2017) states that errors in solving mathematical problems can be divided into three types, those are: concept errors, principle errors and operating errors. Concept errors are errors in using the concepts related to the material, concept errors can occur in students' learning because they are wrong in using the concept of the variable. Principal errors are errors relating to the relationship between two or more mathematical objects, one of the principle errors can occur because the students are wrong in using formula and translating the problem. Operation errors are errors in doing calculations, operation errors can occur because the students do not use operating rules or calculations correctly. Meanwhile, according to Lerner in Nurjanatin (2017), present the common several of errors made by children in doing mathematical tasks, those are lack of knowledge about symbols, place values, incorrect use of processes, calculation errors, and writing that cannot be read clearly.

Based on the description above, in this study students' mistakes in drawing graphics were divided into two, those are procedural errors and concept errors. The procedural error in this case is the student's mistake in following the steps of drawing a graphic. Then the concept error here referred to the student's mistake in calculating or putting a curve in the Cartesian diagram.

\section{Research Methods}

This research is descriptive research. Held in SMPN 5 Purwokerto, class IX H, on the PDS (Lecturer Assignment to School) activities. The method of collecting data is with the tests conducted twice to see the changes and the consistency of the data. The sampling was carried out by using the Purposive Sampling technique, with considering the students' clear answers, taking two tests, the changes from the first and second tests.

\section{Results and Discussion}

PBL model learning activities with the strategy true or false assisted by the Geogebra application begins with giving cards that contain statements in the form of questions and answers. There are some questions with right answers and some questions with wrong answers. Students write whether the statements right or wrong on the card then keep it in their pockets and open or check again at the end of the class. At first, students are still inadequate in writing the answer, even though this activity is not required to count, just write right or wrong. the students look a little longer in writing right or wrong on the card. However, after getting used to the learning model, students are faster in writing right and wrong on the cards.

The giving card-activity has changed the way of learning to be more enthusiastic and cheerful. Students get a surprise at the end of learning, when they check what they write on the card is appropriate or not. This activity has been a very good feedback for teachers. Students can find out which problems with the right solution or not. This activity is also one of the things that 


\section{LUKMANUL AKHSANI, ERLIN NURHAYATI}

Peningkatan The Error in Drawing Graphic of Quadratic Function in PBL Model

shows whether students are happy with the learning that has been followed or not. If students enjoy learning, it can make students easy to understand the material that has been taught, that is drawing a graph of quadratic functions.
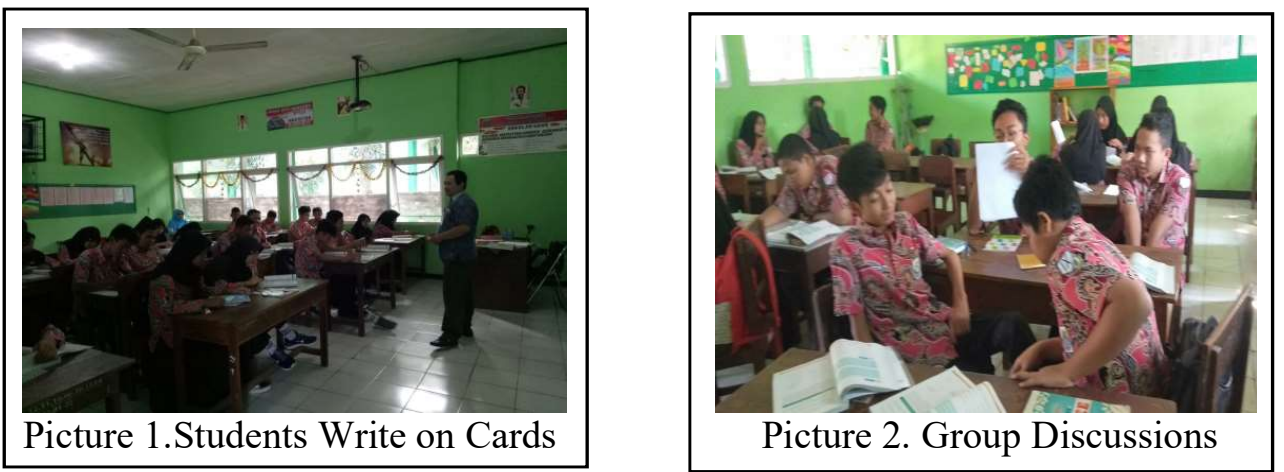

After students had been given a card and keept it in their pockets, then the teacher asked students to gather in some groups. Students in groups discussed to complete the tasks that were given in the form of LKPD. Then students presented the results of their discussion. Furthermore students, together with the teacher, concluded the material. Before the class ended, students opened cards from their pockets and together checked whether their answers were appropriate or not. In this activity, it was a surprise for students because they just know that some of their answer was appropriate and some others were not. This activity can be a reinforcement of students' understanding of the material that has been studied.
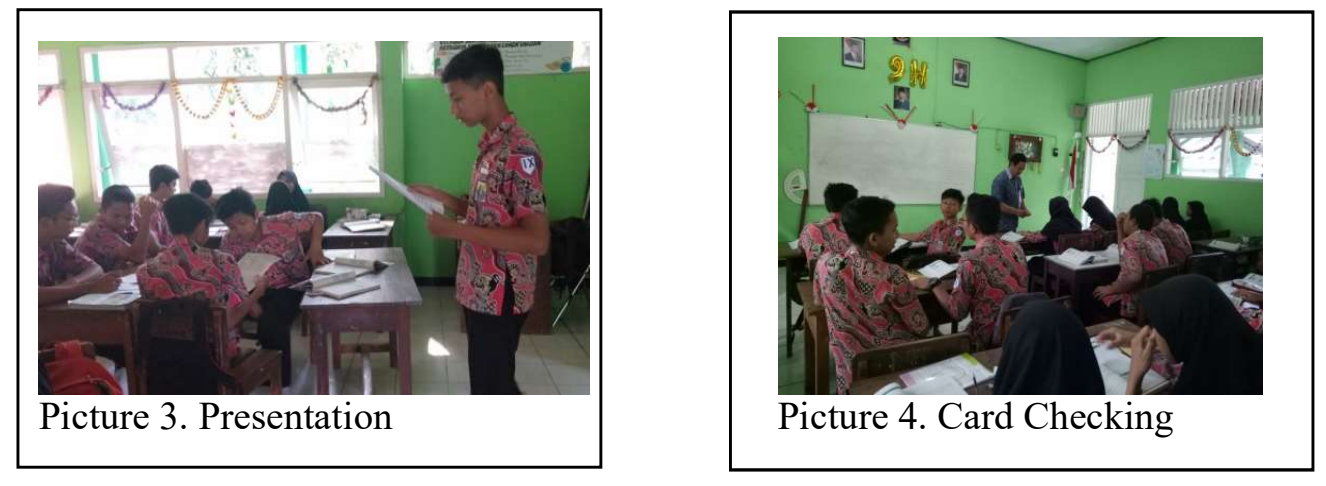

Drawing quadratic function graphs consists of several activities, those are drawing graphs $\mathrm{f}(\mathrm{x})$ $=\mathrm{ax}^{2}, \mathrm{f}(\mathrm{x})=\mathrm{x}^{2}+\mathrm{c}, \mathrm{f}(\mathrm{x})=\mathrm{x}^{2}+\mathrm{bx}$, symmetry axis and optimum value, shifting quadratic function graphs and sketches quadratic function graphs. The teacher gives LKPD and when there is no problem of drawing the graph in the discussion, because there have been clear guidelines and sequences to arrive at conclusions. In the subject matter of drawing graphs the function $y=a^{2}$, $y=x^{2}+c, y=x^{2}+b x$ students determine the points and put on the Cartesian diagram by themselves. the subject matter of symmetry axis and optimum value, and the subject matter of shifting of quadratic functions, the picture is already in LKPD. Students are asked to write down their reasoning so they could draw conclusions where the curve must be shifted.

The test is done twice. First, after students learn to draw a graph $f(x)=a x^{2}$ and $f(x)=x^{2}+c$, students are given a test to draw a graph. The next test is done after studying the material $\mathrm{f}(\mathrm{x})$ $=\mathrm{x}^{2}+\mathrm{bx}$, the axis of symmetry, and the optimum value shifting the graph of quadratic 


\section{AlphaMath \\ Journal of Mathematics Education, 6(2) November 2020}

functions. The questions that are given to the student have the same form. Students are asked to draw the function $\mathrm{f}(\mathrm{x})=\mathrm{x}^{2}+\mathrm{c}$ by shifting the function $\mathrm{f}(\mathrm{x})=\mathrm{x}^{2}$; the first test draws $\mathrm{f}(\mathrm{x})=$ $x^{2}-6$ and the next test draws $f(x)=x^{2}+3$. These test are done in order to get data about the form of errors in drawing graphics. The results of the tests is also vary.

The first sample (S1), in the first test shows a concept error. S1 starts by drawing a graph $\mathrm{f}(\mathrm{x})$ $=x^{2}$, then drawing graph $\mathrm{f}(\mathrm{x})=\mathrm{x}^{2}-6 . \mathrm{S} 1$ doesn't do correctly in shifting the graph. From the 5 points that have been made, 2 points are wrong in sliding. that should be shifted down 6 units, but two points moved 4 points down. After that on the second test, S1 has answered with the correct procedure, which is drawing $f(x)=x^{2}$ first, then shift it to get the graph $f(x)=x^{2}+3$. However, not all points are correctly shifted up as far as 3 units, there are two points in the middle of the curve which are shifted only in two units. The two tests that were followed, S1 still made a mistake in shifting the curve.

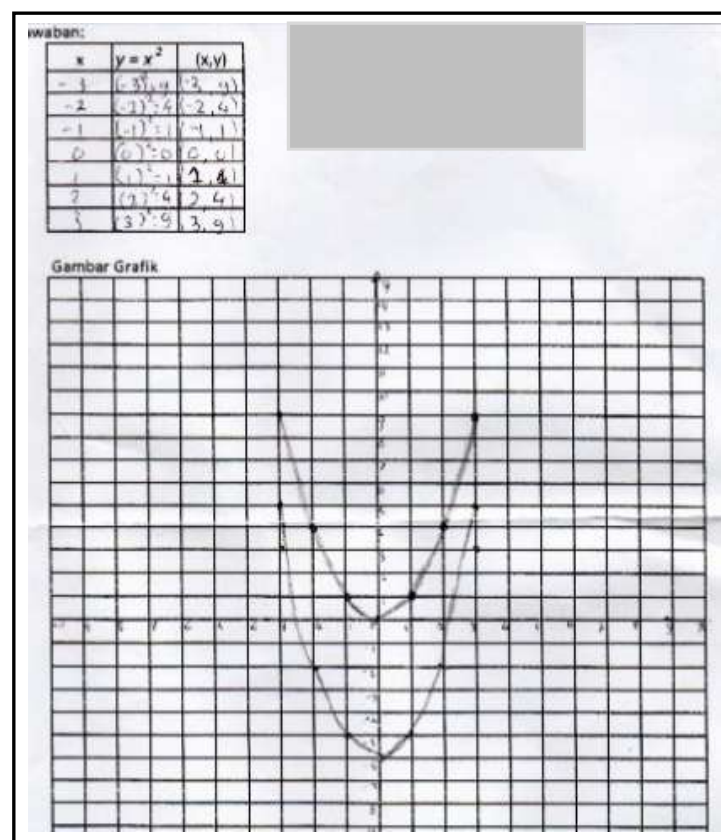

Picture 5. S1's answer (test I)

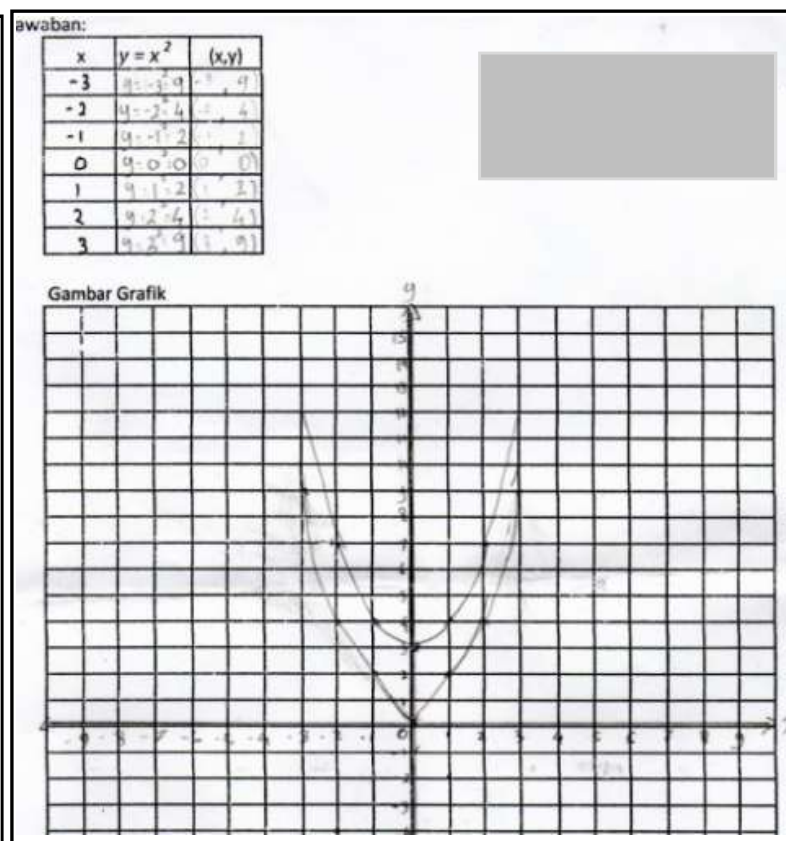

Picture 6. S1's answer (test II)

The second sample (S2), in the first test S2 directly draw a graph $\mathrm{f}(\mathrm{x})=\mathrm{x}^{2}-6$ without drawing $f(x)=x^{2}$ first. The points entered directly from $f(x)=x^{2}$ then the coordinates y minus 6 . It is not wrong conceptually, because for this first task, in finding the point can be done by changing the coordinates of y. However, what was asked in the task is not like that. The first task is that the student are asked to draw a graph $\mathrm{f}(\mathrm{x})=\mathrm{x}^{2}$ first, then draw a graph $\mathrm{f}(\mathrm{x})=\mathrm{x}^{2}-6$. This shows $\mathrm{S} 2$ make a procedure error. In the second test, $\mathrm{S} 2$ only draws graphs $\mathrm{f}(\mathrm{x})=\mathrm{x}^{2}$, they do not draw graphs $f(x)=x^{2}+3$. S2 has added 3 units of the original coordinate $y$. But when they draw the graph, $\mathrm{S} 2$ has not been able to shift the graph $\mathrm{f}(\mathrm{x})=\mathrm{x}^{2}$ up as far as 3 units. This shows the procedure that must be done by $\mathrm{S} 2$ has not been done. 

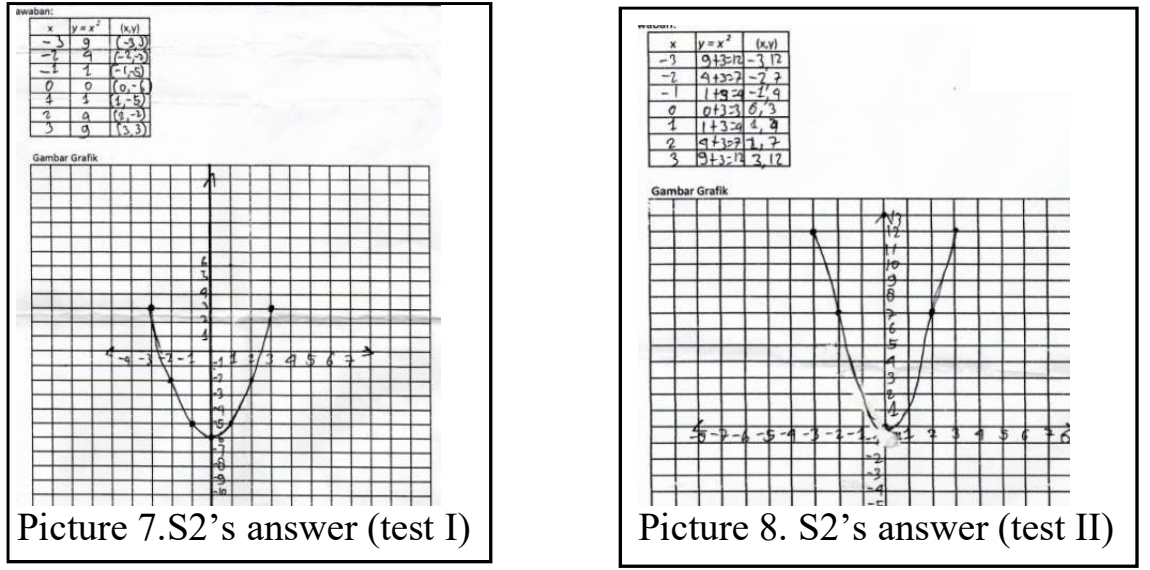

The third ample (S3), in the first test did the same thing as S2. Draw directly graph $f(x)=x^{2}-6$, without drawing graph $\mathrm{f}(\mathrm{x})=\mathrm{x}^{2}$, than shifted 6 units down. In the second test, S3 make a concept error that they supposed to shift the graph $f(x)=x^{2}$ as far as 3 units up, but 4 of the 5 points are made wrong in shifting. There are shifted only 1 unit, 2 units and 4 units. This shows S3 is not able to understand the concept of shifting the curve $f(x)=x^{2}+3$.
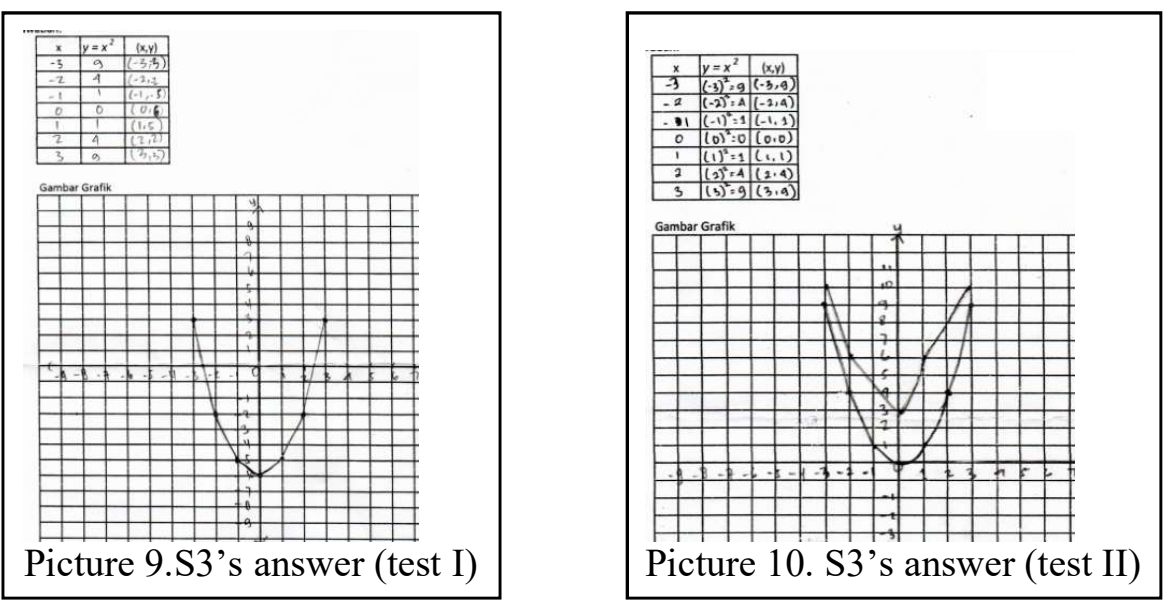

Students answer according to their understanding. The explanation shown above is the student who made a mistake, made a mistake again on the second test. There are also students who made mistakes on the first test, but the second test was correct. the forth sample (S4), in the first test made a procedural error as was done by $\mathrm{S} 2$ and $\mathrm{S} 3$, that they directly draw a graph $\mathrm{f}(\mathrm{x})$ $=x^{2}-6$. In the second test, $S 4$ is correct in answering the task, that is shifting the graph $f(x)=x^{2}$ as far as 3 units up to get the graph $f(x)=x^{2}+3$. 

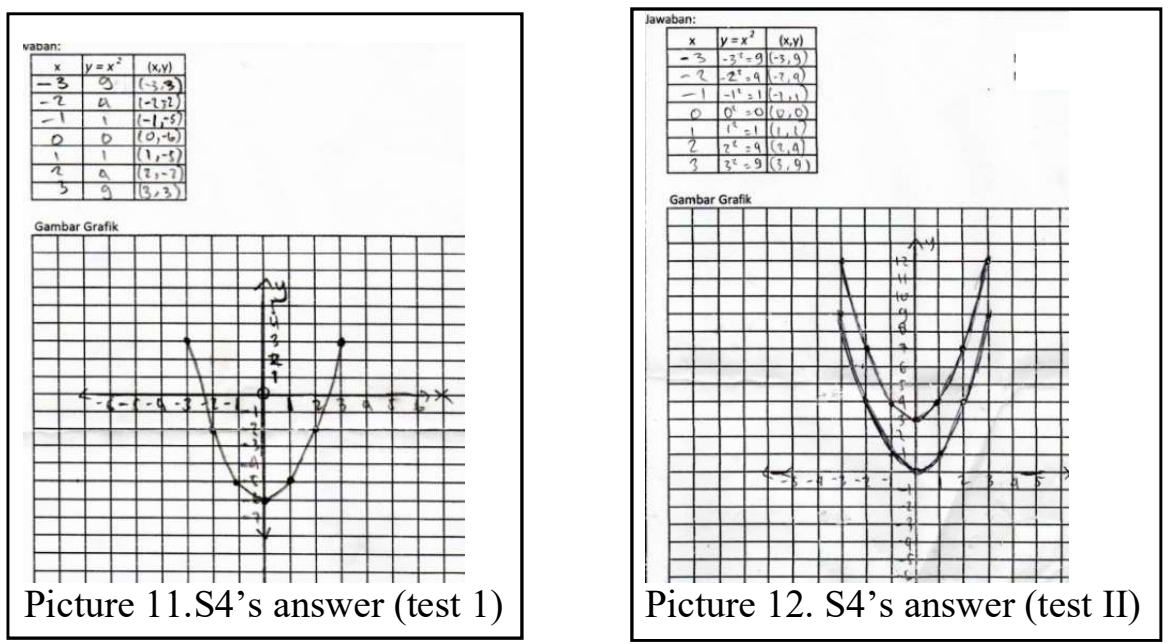

Overall, on the first and second tests, students do not always make mistakes. Many of them answered correctly. The details are as follows.

Table 1

The percentage of student answers

\begin{tabular}{llll}
\hline No & Valuation & Test I & Test II \\
\hline $\mathbf{1}$ & Correct & $29,63 \%$ & $74,07 \%$ \\
$\mathbf{2}$ & Concept error & $7,41 \%$ & $11,11 \%$ \\
$\mathbf{3}$ & Procedural error & $62,96 \%$ & $14,82 \%$ \\
\hline
\end{tabular}

The table above shows that procedural errors still dominate. For either the first or second test, procedural errors are more than conceptual errors. This is compatible with the results of Priyati's research (2018), that the mistakes often made by students are procedural errors in the amount of $71.23 \%$. While conceptual errors have a lower percentage in the amount of $28.77 \%$. Then, judging from the results of the test, learning PBL models with true or false strategies assisted by the Geogebra application can be one of the alternative choices for the teacher to solve the problem in drawing graphs of quadratic function. This is compatible with the results of Siregar's research (2017), which the use of Geogebra simulations is significantly effective in learning quadratic function graphs, the use of Geogebra simulations in learning quadratic function graphs can improve students' ability to recognize the characteristics of quadratic function graphs. PBL can be instrumental in equipping teachers to meet demands of an arduous profession (Shields \& Du, 2000). And, to improve students' achievement, schools must adapt the PBL method carefully (Argaw et al., 2017).

\section{Conclussion}

The conclusion of this research is that the error in drawing quadratic function graphs is dominated by procedural errors. PBL model with true or false strategy assisted by Geogebra application can be an alternative learning to solve students' mistakes in drawing graphs of quadratic functions. As for suggestions, research or analysis can be done more deeply related to increasing the ability of students to draw a graph of quadratic functions.

\section{References}

Argaw, A. S., Haile, B. B., Ayalew, B. T., \& Kuma, S. G. (2017). The effect of problem based learning (PBL) instruction on students' motivation and problem solving skills of physics. 
Eurasia Journal of Mathematics, Science and Technology Education, 13(3), 857-871. https://doi.org/10.12973/eurasia.2017.00647a

Arief, H. S., \& Sudin, A. (2016). Meningkatkan Motivasi Belajar Melalui Pendekatan ProblemBased Learning (Pbl). Meningkatkan Motivasi Belajar Melalui Pendekatan ProblemBased Learning (Pbl), 1(1), 141-150. https://doi.org/10.23819/pi.v1i1.2945

Erikalisdiana, D. S., \& Jayadinata, A. K. (2016). PENGARUH PENGGUNAAN STRATEGI TRUE OR FALSE TERHADAP HASIL. Jurnal Pena Ilmiah, 1. https://ejournal.upi.edu/index.php/penailmiah/article/view/3565/pdf

Nafiah, Y. N., \& Suyanto, W. (2014). Penerapan model problem-based learning untuk meningkatkan keterampilan berpikir kritis dan hasil belajar siswa. Jurnal Pendidikan Vokasi, 4(1), 125-143. https://doi.org/10.21831/jpv.v4i1.2540

Nurjanatin, I. \& Sugondo, G, Manuwung, MMH. Analisis Kesalahan Peserta Didik dalam Menyelesaikan soal cerita pada Materi Luas Permukaan Balok di Kelas VIII-F Semester II SMP N 2 Jayapura. Jurnal Ilmiah Matematika dan Pembelajaran. Vol 2, No. 1, Juli 2017. Hal 22-31. [https://ejournal.uncen.ac.id/index.php/JIMP/article/view/252]

Layn, MR. \& Muhammad Syahrul K. Analisis Kesalahan Siswa Dalam Menyelesaikan Soal Cerita Matematika. Jurnal Math Educator Nusantara. Volume 3 Nomor 2, Nopember 2017. [http://ojs.unpkediri.ac.id/index.php/matematika/article/download/855/725]

Priyati. \& Helti LM. 2018. Pemberian Scaffolding Untuk Siswa Yang Mengalami Kesalahan Dalam Menggambar Grafik Fungsi Kuadrat. Jurnal Teori dan Aplikasi Matematika. Vol.2, No. 1, April 2018, Hal. 87-95.[http://journal.ummat.ac.id/index.php/jtam/article/view/293]

Shields, D. N., \& Du, S. (2000). A fault detection method for a three-tank system. Systems Science, 26(2), 27-41.

Silberman, Melvin L. 2007. Active Learning (diterjemahkan Sarjuli.dkk). Yogyakarta: Pustaka Insan Madani.

Siregar, S. 2017. Efektivitas Penggunaan Simulasi Geogebra Pada Pembelajaran Grafik Fungsi Kuadrat. Edumatica. Volume 07 Nomor 01 April 2017. [https://onlinejournal.unja.ac.id/edumatica/article/view/3870]

Shofiyah, N., \& Wulandari, F. E. (2018). Model Problem Based Learning (Pbl) Dalam Melatih Scientific Reasoning Siswa. Jurnal Penelitian Pendidikan IPA, 3(1), 33. https://doi.org/10.26740/jppipa.v3n1.p33-38

Supiandi, M., \& Julung, H. (2016). Pengaruh Model Problem Based Learning (PBL) terhadap Kemampuan Memecahkan Masalah dan Hasil Belajar Kognitif Siswa Biologi SMA. JPS (Jurnal Pendidikan Sains), 4(2), 60-64. https://doi.org/10.17977/jps.v4i2.8183

Trianto. 2014. Mendesain Model Pembelajaran Inovatif, Progresif dan Kontekstual. Jakarta: Prenadamedia Group. 